\title{
Effects of emersion-induced hypoxia on some haemolymph constituents of Nephrops norvegicus
}

\author{
C. J. Bernasconi, R. F. Uglow* \\ University of Hull, Department of Biological Sciences, Cottingham Road, Hull HU6 7RX, UK
}

\begin{abstract}
The effects of prolonged emersion $(24,48$ and $72 \mathrm{~h}$ ) and subsequent re-immersion on Nephrops norvegicus (L.) held at $5^{\circ} \mathrm{C}$ were assessed using an index of physical quality criteria and a suite of haemolymph constituent assays. Collectively, these showed classical hypoxia-induced changes over $48 \mathrm{~h}$ of emersion, but, subsequently, between 48 and $72 \mathrm{~h}$ emersion, physical activity, haemolymph $\mathrm{pH}$ and circulating levels of urate, free amino acids and major ions all returned to normal (control) levels, and L-lactate levels had started to decrease towards control levels. These patterns of changes differed from that of the haemolymph total ammonia levels which continued to increase linearly throughout emersion. $N$. norvegicus appeared to partially compensate for the post$48 \mathrm{~h}$ emersion increased levels by increasing the production, and hence relative proportions, of other less toxic nitrogenous metabolites. The data replicated that of preliminary trials. Working on the presumption that such events could occur only in the presence of oxygen, possible sources of such oxygen under prolonged hypoxia are discussed. The low holding temperature appears to be the key to prolonged survival of $N$. norvegicus, and the switch from anaerobic to aerobic respiration itself appears to be a function of a preceding, prolonged period of hypoxia. The ecological and commercial implications for a burrow-dwelling, benthic animal that may experience episodic periods of hypoxia and which forms a highly important proportion of the value of total UK commercial landings are discussed.
\end{abstract}

KEY WORDS: Hypoxia $\cdot$ Nephrops norvegicus $\cdot$ Emersion

\section{INTRODUCTION}

Crustaceans are principally aquatic but have evolved to occupy diverse habitats within and between which environmental conditions differ markedly. Furthermore, the physiological status of crustaceans is also a variable and alters with their activity levels and reproductive and moulting cycles (Bridges 2001). Crustacean haemolymph has evolved to perform a variety of functions, including the carriage of oxygen and metabolic wastes, which facilitate survival in these diverse habitats. The major protein fraction of marine crustaceans is the respiratory pigment haemocyanin, the functional role of which within a changing environment has been a source of interest for many years (Morris 1990, Truchot 1992, Terwilliger 1998). Large, quantitative changes to haemocyanin concentration may occur during moulting or exposure to a salinity extreme and reflect extracellular volume adjustments rather than biosynthesis or catabolism, but synthesis is known to be stimulated by hypoxia (Hagerman \& Uglow 1985) and catabolism by starvation (Uglow 1969).

Emersion-induced hypoxia compromises $\mathrm{O}_{2}$-dependent processes because of the impaired fluxes of $\mathrm{O}_{2}$ and $\mathrm{CO}_{2}$ and the consequent anaerobiosis. Internal hypercapnic hypoxia is thus a frequent consequence of emersion (DeFur 1988, Taylor \& Whiteley 1989). In addition to exacerbating hypercapnic acidosis through a metabolic acidosis, the concentrations of other potential organic modulators of haemocyanin oxygen affinity $\left(\mathrm{HcyO}_{2}\right)$ - including L-lactate and urate - are also elevated as a consequence of hypoxia (Morris et al. 1985, Burnett 1992, Morris 1990, 1991). Changes to 
haemolymph strong ion concentrations, consequent on acid-base regulation, can alter $\mathrm{Ca}^{2+}$ and $\mathrm{Mg}^{2+}$ concentrations that can modulate the $\mathrm{HcyO}_{2}$ in some crustaceans (Truchot 1983, Morris 1991, Danford et al. 2002).

Many decapod crustacean species experience emersion naturally. Such periods may comprise a proportion of the tidal cycle, a seasonal dry period or be almost continual. Other species (e.g. benthic, burrowing or infaunal species) may experience sporadic or periodic periods of intense hypoxia. These low oxygen events impair gill function and cause supranormal haemolymph and tissue ammonia levels (Regnault 1992, Schmitt \& Uglow 1997, Danford et al. 2001a). The severity of emersion- or hypoxia-induced respiratory acidosis depends partly on the functioning characteristics of the haemocyanin (Hcy) and the extent to which its function becomes optimised (Danford et al. 2001b). An increase in tissue ammonia levels has been shown to affect the regulation of haemolymph $\mathrm{Na}^{+}, \mathrm{Ca}^{2+}$ and $\mathrm{Cl}^{-}$(Rebelo et al. 1999, Danford et al. 2002), which may ultimately affect nervous function.

Free amino acids (FAA) are among the most important non-protein fractions of nitrogen in crustaceans. They are known to be involved in the active adjustment of intracellular osmoregulation in marine invertebrates with the major FAAs being glycine, alanine, praline, glutamic acid, taurine and aspartic acid (Gilles 1979, Claybrook 1983). Glycine, proline and alanine show the rapid, important adjustments necessary for osmoregulation following changes in osmotic stress (Bishop \& Burton 1993).

The aim of the present study was to investigate the effects of emersion-induced hypoxia on the Hcy, $\mathrm{pH}$, total protein, L-lactate, urate, ammonia and FAA levels, as well as some ion concentrations in the haemolymph of Nephrops norvegicus (L.). The objective was to better determine the tolerance and physiological responses of this species to prolonged emersion (up to $72 \mathrm{~h}$, corresponding to a possible commercial distribution envelope from the UK to Pacific Rim country destinations).

\section{MATERIALS AND METHODS}

Nephrops norvegicus were trap-caught off the northwestern coast of Scotland and transported, emersed in polystyrene boxes containing an ice gel pack, to the laboratory at Hull University, where they were maintained in plastic, opaque tanks (1.5 m inner diameter, 500 l) supplied with biologically filtered, recirculating, aerated seawater at a constant $5 \pm 1^{\circ} \mathrm{C}$ at a salinity of 35 with artificial light set at a photoperiod of $12 \mathrm{~h}$ light:12 h dark. Salinity was measured daily with a hand-held refractometer (Atago), and total ammonia (TA) levels in the aquaria were monitored and not allowed to rise above $100 \mu \mathrm{mol} \mathrm{TA} \mathrm{l}^{-1}$. Experimental animals, unsorted for gender, were maintained unfed in such conditions for a minimum of $48 \mathrm{~h}$ prior to experimentation to allow acclimatisation.

Groups of 6 adult Nephrops norvegicus (mean weight $37.50 \pm 4.16 \mathrm{~g})$ were emersed for different periods: $0 \mathrm{~h}$ (control), $24 \mathrm{~h}$ and $72 \mathrm{~h}$. A further group ( $\mathrm{n}=$ 36) was emersed for $48 \mathrm{~h}$. Experimental emersion was accomplished by carefully removing each lobster from the water and packing it in a polystyrene box with newspaper and a large gel ice pack. The boxes were stored for the appropriate emersion period in a temperature-controlled room $\left(5 \pm 1^{\circ} \mathrm{C}\right)$. Following the $48 \mathrm{~h}$ emersion period, the box was unpacked and 30 ind. were re-immersed in a large aerated tank containing biologically filtered seawater.

Quiescent Nephrops norvegicus were bled using a sterile $2 \mathrm{ml}$ syringe (Hamilton), the needle $(23 \mathrm{~g}$ ) of which was inserted either into the arthrodial membrane at the base of the walking legs or beneath the cephalothorax and into the pericardium. Separate groups ( $\mathrm{n}=6$ in all cases) of lobsters were bled before being emersed (control), at the end of 24, 48 and $72 \mathrm{~h}$ of emersion and, for the 48 h-emersed ind. only, after 2 , $6,12,24$ and $48 \mathrm{~h}$ after being re-immersed (total = 54 ind.). No lobster was bled more than once. Blood samples were divided into 3 portions and kept on ice. One subsample $(0.5 \mathrm{ml})$ was diluted $1: 1$ (v:v) with ultra pure water for FAA and TA analyses; another subsample $(0.25 \mathrm{ml})$ was deproteinised with $1: 1$ (v:v) $6 \%$ perchloric acid for urate and L-lactate measurements, and the remaining subsample $(0.5 \mathrm{ml})$ was diluted $1: 1(\mathrm{v}: \mathrm{v})$ with tetramethyl ammonium hydroxide (TMAH) for ionic composition determinations. All samples were frozen immediately $\left(-20^{\circ} \mathrm{C}\right)$ until required. The mortality and condition of surviving individuals after 24, 48 and $72 \mathrm{~h}$ were assessed in all experiments using an index of overt condition (Table 1).

The concentrations of $\mathrm{Na}^{+}, \mathrm{K}^{+}, \mathrm{Ca}^{2+}, \mathrm{Mg}^{2+}$ and $\mathrm{Cu}^{2+}$ ions in the TMAH-diluted haemolymph were determined using inductively coupled plasma optical emission spectrometry (ICP-OES). Gas chromatographymass spectroscopy (GC-MS) was used to measure the haemolymph free amino acid pool (FAA).

Haemolymph L-lactate was measured using Trinity Biotech diagnostic kit no. 735-10 and haemolymph urate using Sigma diagnostic kit no. 685. Ammonia concentrations were measured using a flow-injection gas diffusion system (Hunter \& Uglow 1986).

Haemolymph protein concentrations were measured using a hand-held refractometer (Atago). Haemocyanin was determined spectrophotometrically using $20 \mu \mathrm{l}$ of freshly collected whole blood diluted with 
Table 1. Index of overt condition

\begin{tabular}{|c|c|c|}
\hline \multicolumn{2}{|c|}{ Strength index } & Description \\
\hline 1 & Strong & $\begin{array}{l}\text { Strong limb movement, no drooping of } \\
\text { limbs }\end{array}$ \\
\hline 2 & Medium & $\begin{array}{l}\text { Limb and claw movement, relatively } \\
\text { strong but with slight drooping of limbs }\end{array}$ \\
\hline 3 & Weak & $\begin{array}{l}\text { Minimal limb movement, drooping of } \\
\text { limbs but slight strength in claws, } \\
\text { mouthparts slightly open }\end{array}$ \\
\hline 4 & Moribund & $\begin{array}{l}\text { No limb or claw movement, complete } \\
\text { hanging of all limbs, eyes sunken, } \\
\text { mouthparts open, some movement of } \\
\text { antennae }\end{array}$ \\
\hline 5 & Dead & As level 4 but no movement of antennae \\
\hline
\end{tabular}

$980 \mu \mathrm{l}$ of ultra pure water in a $10 \mathrm{~mm}$ quartz cuvette. Absorbance was measured at $335 \mathrm{~nm}$ using a Pharmacia Biotech Novaspec II spectrophotometer and the haemocyanin concentration ( $\mathrm{mmol} \mathrm{l}^{-1}$ ) calculated from the molar extinction coefficient.

All data are represented as means \pm SE. Datasets of equal variances were compared using a $t$-test or ANOVA. Data of unequal variance were compared with the non-parametric Kruskal-Wallis test. Statistical comparisons were made at the $\mathrm{p}<0.05$ level.

\section{RESULTS}

Nephrops norvegicus survived emersion for up to $72 \mathrm{~h}$. Only 1 specimen died between 48 and $72 \mathrm{~h}$ of emersion and another during the $2 \mathrm{~h}$ re-immersion period. At the end of the $48 \mathrm{~h}$ emersion period, lobsters were very quiescent and no tail flipping was observed. After $72 \mathrm{~h}$ emersion the lobsters were observed to be active with tail flipping, suggesting a possible change had occurred between the 48 and $72 \mathrm{~h}$ emersion periods.

The control group haemolymph mean $\mathrm{pH}$ was $7.73 \pm$ 0.03, which was significantly higher than the mean haemolymph $\mathrm{pH}$ after $48 \mathrm{~h}$ emersion $(7.27 \pm 0.04 ; F=$ 3.90, p < 0.05) (Fig. 1). A significant difference was also found between the $48 \mathrm{~h}$-emersed group and the 24 and $72 \mathrm{~h}$ emersion group $(F=3.90, \mathrm{p}<0.05)$. The $2 \mathrm{~h}$ reimmersion period appeared to be sufficient to restore the blood $\mathrm{pH}$ values to means not significantly different from that of the control group (Fig. 1). The increased $\mathrm{pH}$ after 2, 6, 12, 24 and $48 \mathrm{~h}$ re-immersion was significantly higher than the mean value prior to re-immersion (48 $\mathrm{h}$ emersion) $(t=4.95,6.26,4.77,5.31$ and 3.34, respectively, p's < 0.05).

Haemolymph protein concentrations were highly variable and no significant between-group differences were found (Fig. 1). Concentrations showed a general trend of being higher than the control group values after 24 and $48 \mathrm{~h}$ emersion but decreased after $72 \mathrm{~h}$ emersion. The post-48 h emersion mean haemolymph protein concentration decreased following re-immersion in all but the $48 \mathrm{~h}$ re-immersed group.

Haemolymph L-lactate concentrations increased during emersion with the largest increase in the $48 \mathrm{~h}$ emersion group, which had a mean value significantly higher than that of the control value or those of the 24 and $72 \mathrm{~h}$ emersion groups $(F=3.53, \mathrm{p}<0.05)$ (Fig. 1). During re-immersion, L-lactate concentrations decreased significantly ( $\mathrm{p}<0.05$ ), but were still higher than pre-emersion levels after $2 \mathrm{~h}$. Concentrations of L-lactate continued to decrease over the subsequent re-immersion periods and were not detectable after $24 \mathrm{~h}$ re-immersion, but increased again to $0.05 \pm$ $0.02 \mathrm{mmol} \mathrm{l}^{-1}$ after $48 \mathrm{~h}$ re-immersion.

The mean haemolymph urate concentration for the immersed (control) group was $0.04 \pm 0.01 \mathrm{mmol} \mathrm{l}^{-1}$. A statistically significant increase occurred after $24 \mathrm{~h}$ emersion $(t=3.03, \mathrm{p}<0.05)$ and a further, non-significant increase occurred after $48 \mathrm{~h}$ emersion (Fig. 1). After $72 \mathrm{~h}$ emersion, urate concentration decreased to a value not significantly different to the control $(\mathrm{p}=$ 1.00) but significantly less than the 24 and $48 \mathrm{~h}$ emersion concentration $(F=4.18, \mathrm{p}<0.05)$. In the reimmersed 48 h-emersed groups, urate concentrations had decreased significantly within $24 \mathrm{~h}(t=1.84, \mathrm{p}<$ 0.05 ) but, after $48 \mathrm{~h}$ re-immersion, urate concentrations had returned to control values.

Haemocyanin concentrations (Fig. 1) did not change significantly during treatments and the overall mean for all lobsters tested during emersion and re-immersion was $0.43 \pm 0.08$ and $0.59 \pm 0.08 \mathrm{mmol} \mathrm{l}^{-1}$ respectively. The mean haemocyanin concentrations showed a negative linear relationship with emersion duration and decreased by $0.20 \mathrm{mmol} \mathrm{l}^{-1}$ over $72 \mathrm{~h}$ of emersion. Haemolymph haemocyanin increased rapidly on reimmersion and had returned to pre-emersion levels within $2 \mathrm{~h}$.

The mean haemolymph TA of immersed (control) Nephrops norvegicus was $43.90 \pm 2.39 \mu \mathrm{mol} \mathrm{TA}{ }^{-1}$. During emersion, TA accumulated in the haemolymph of all lobsters and showed a positive linear relationship with emersion duration $(y=204.53 x-$ 188.48, $\mathrm{R}^{2}=0.9671$ ) (Fig. 1). These final concentrations were significantly higher than the control value in the 48 and $72 \mathrm{~h}$ emersed groups $(F=9.4$, $\mathrm{p}<0.05$ in each case).

After $12 \mathrm{~h}$ re-immersion following a $48 \mathrm{~h}$ emersion period, haemolymph ammonia had decreased significantly $(t=2.08, \mathrm{p}<0.05)$ and remained significantly lower than the emersion concentrations throughout the remaining $36 \mathrm{~h}$ re-immersion period $(t=1.31, \mathrm{p}<0.05)$ (Fig. 1). The haemolymph ammonia concentration 

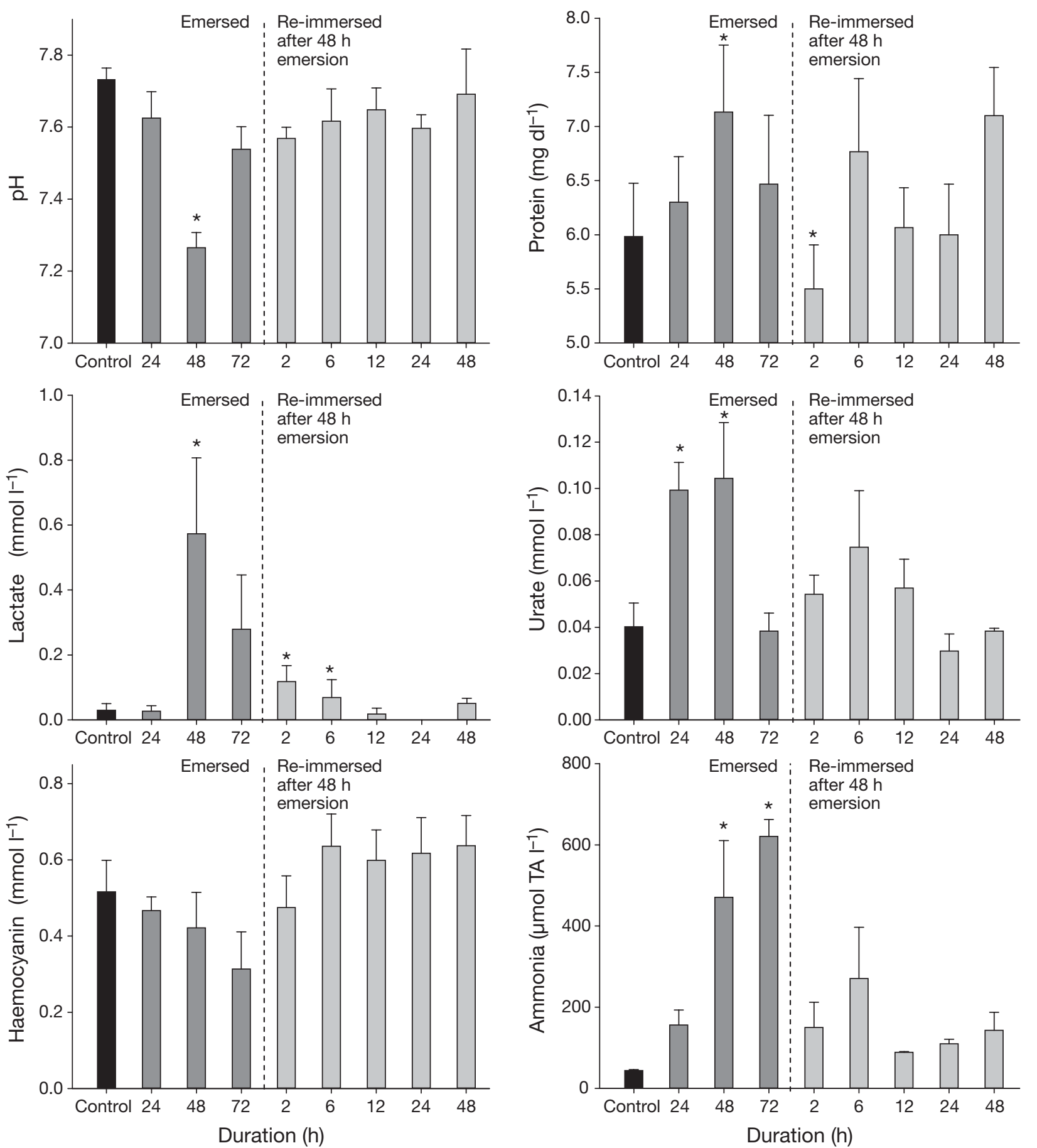

Fig. 1. Nephrops norvegicus. Haemolymph $\mathrm{pH}$, protein, L-lactate, urate, haemocyanin and ammonia concentrations after 0 (control), 24, 48 and $72 \mathrm{~h}$ emersion and after a 2, 6, 12, 24 and $48 \mathrm{~h}$ re-immersion period. TA: total amonia. Values are mean $\pm \mathrm{SE}$ $(\mathrm{n}=6) .{ }^{*}$ : Significantly different from the control mean

after $48 \mathrm{~h}$ re-immersion following $48 \mathrm{~h}$ emersion was not significantly different from the control value $(\mathrm{p}=$ 1.00).

Haemolymph concentrations of the major ions in emersed and re-immersed Nephrops norvegicus are given in Fig. 2. $\mathrm{Cu}^{2+}$ did not alter significantly throughout the investigation $(p=1.00)$. Mean $\mathrm{Na}^{+}$ concentration of the control group $(0 \mathrm{~h})$ was $543.81 \pm$ $4.33 \mathrm{mg} \mathrm{l}^{-1}$ which decreased significantly to $462 \pm$ $19.56 \mathrm{mg} \mathrm{l}^{-1}$ over $48 \mathrm{~h}$ of emersion $(t=3.54, \mathrm{p}<$ 0.05). $\mathrm{Na}^{+}$concentrations after $48 \mathrm{~h}$ emersion were also significantly lower than subsequent emersion 

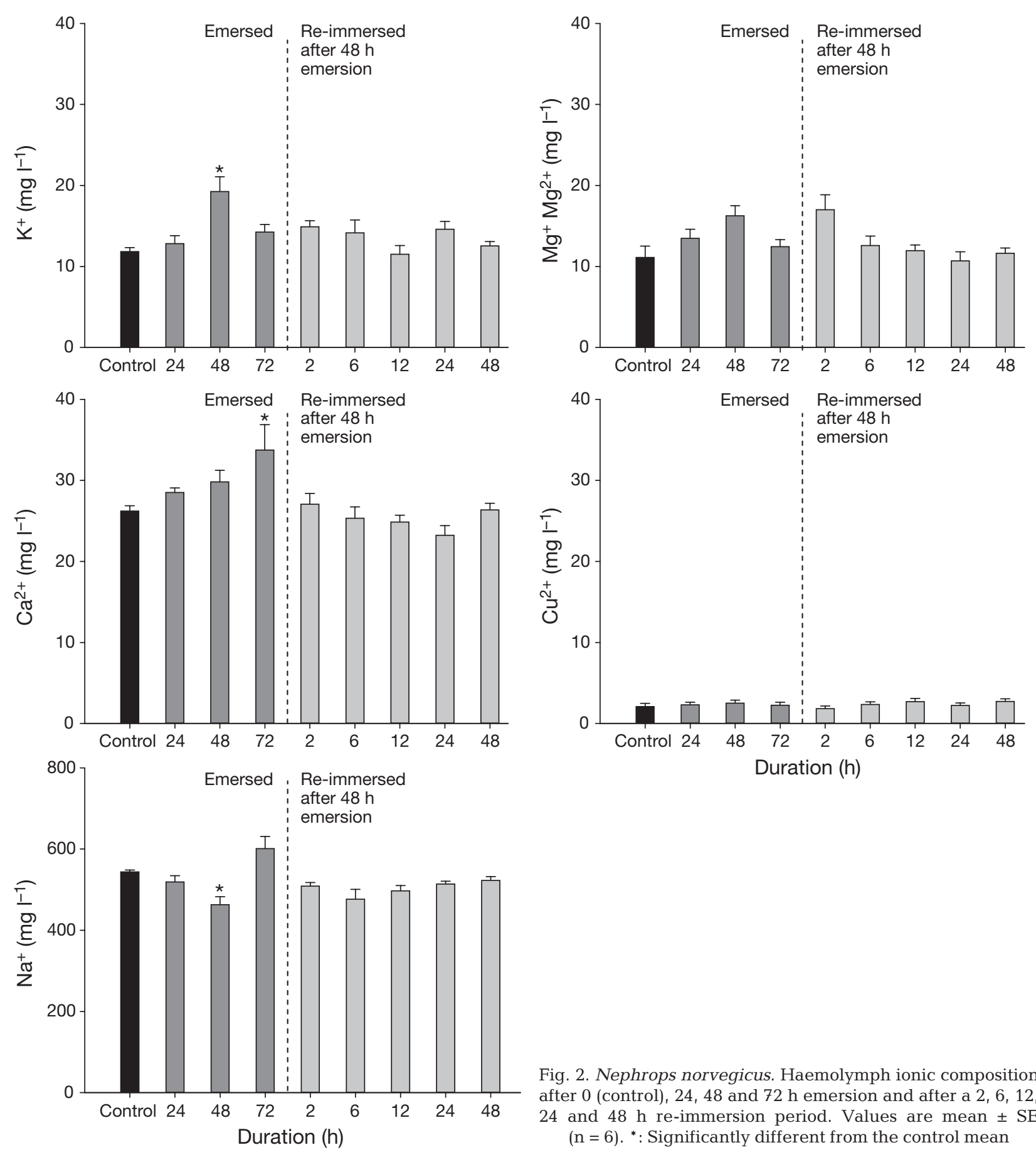

Fig. 2. Nephrops norvegicus. Haemolymph ionic composition after 0 (control), 24, 48 and $72 \mathrm{~h}$ emersion and after a 2, 6, 12, 24 and $48 \mathrm{~h}$ re-immersion period. Values are mean $\pm \mathrm{SE}$ $(\mathrm{n}=6) .{ }^{*}$ : Significantly different from the control mean

values after 24 or $72 \mathrm{~h},(519.02 \pm 15.31$ and $601.16 \pm$ $29.58 \mathrm{mg} \mathrm{l}^{-1}$ respectively) $(t=2.04$ and 4.39 , respectively, p's $<0.05)$. After $2 \mathrm{~h}$ of re-immersion, $\mathrm{Na}^{+}$ concentrations had returned to pre-emersion levels ( $\mathrm{p}>0.05)$.

Mean $\mathrm{Ca}^{2+}$ concentrations showed a direct linear relationship with emersion duration (Fig. 2). After $72 \mathrm{~h}$ of emersion, $\mathrm{Ca}^{2+}$ concentrations $\left(33.74 \pm 3.14 \mathrm{mg} \mathrm{l}^{-1}\right)$ had increased significantly compared with the control value $\left(26.23 \pm 0.63 \mathrm{mg} \mathrm{l}^{-1} ; \mathrm{p}<0.05\right) . \mathrm{Ca}^{2+}$ concentrations decreased to levels not statistically different from the control value $2 \mathrm{~h}$ after re-immersion $(\mathrm{p}=1.00)$.

Both $\mathrm{K}^{+}$and $\mathrm{Mg}^{+}$concentrations increased directly with emersion duration for the first $48 \mathrm{~h}$ to reach values significantly higher than the control value for $\mathrm{K}^{+}$ $(t=3.21, \mathrm{p}<0.05)$ but not for $\mathrm{Mg}^{+}(\mathrm{p}>0.05)$. On reimmersion, $\mathrm{K}^{+}$concentrations returned to pre-emersion concentrations after $6 \mathrm{~h}$ re-immersion $(p=1.00)$. In 
Table 2. Nephrops norvegicus. Haemolymph FAA concentrations $\left(\mathrm{mg} \mathrm{l}^{-1}\right)$ before and after emersion and re-immersion. Values are in means \pm SE $(n=6)$

\begin{tabular}{|rlrrrrrr|}
\hline & & Glycine & Alanine & Valine & Leucine & Isoleucine & Proline \\
\hline $0 \mathrm{~h}$ & Control & 20.7 & 9.4 & 0.3 & 0.3 & 0.2 & 5.9 \\
$24 \mathrm{~h}$ & Emersed & 20.1 & 2.2 & 0.2 & 0.2 & 0.2 & 1.2 \\
$48 \mathrm{~h}$ & Emersed & 61.4 & 17.6 & 0.7 & 0.9 & 0.4 & 5.3 \\
$72 \mathrm{~h}$ & Emersed & 15.9 & 4.9 & 0.4 & 0.8 & 0.2 & 2.2 \\
$2 \mathrm{~h}$ & Re-immersed & 10.9 & 3.0 & 0.2 & 0.0 & 0.0 & 0.7 \\
$6 \mathrm{~h}$ & Re-immersed & 16.2 & 14.5 & 3.5 & 5.8 & 2.6 & 4.1 \\
$12 \mathrm{~h}$ & Re-immersed & 0.0 & 2.5 & 0.0 & 0.0 & 0.0 & 0.8 \\
$24 \mathrm{~h}$ & Re-immersed & 7.0 & 1.9 & 0.2 & 0.2 & 0.0 & 1.8 \\
$48 \mathrm{~h}$ & Re-immersed & 20.4 & 6.0 & 3.4 & 5.9 & 3.8 & 8.5 \\
\hline
\end{tabular}

comparison, $\mathrm{Mg}^{+}$levels took $12 \mathrm{~h}$ to return to levels not significantly different than the control value (Fig. 2).

Haemolymph samples were tested for a total of 11 FAA: glycine, alanine, valine, leucine, isoleucine, proline, phenylalanine, histidine, aspartic acid, serine and threonine. Table 2 shows those found and their quantities in $\mathrm{mg} \mathrm{l}^{-1}$. The haemolymph FAA pool of control Nephrops norvegicus was $36.8 \mathrm{mg} \mathrm{l}^{-1}$ (Table 2).

During emersion, a significant increase in glycine had occurred after $48 \mathrm{~h}\left(61.4 \pm 0.45 \mathrm{mg} \mathrm{l}^{-1} ; F=9.62, \mathrm{p}<\right.$ 0.05 ) and this value had decreased significantly after $72 \mathrm{~h}\left(15.9 \pm 0.01 \mathrm{mg} \mathrm{l}^{-1}\right)$ to levels that were not significantly different to the control value $\left(20.7 \pm 1.60 \mathrm{mg} \mathrm{l}^{-1}\right)$. With the exception of proline, all the FAAs had increased levels after $48 \mathrm{~h}$ emersion. Proline levels decreased during the first $24 \mathrm{~h}$ but had returned to control levels after $48 \mathrm{~h}$ emersion $(\mathrm{p}=1.00)$. After re-immersion, each FAA varied in its behaviour, but, generally, glycine, alanine and proline followed significantly decreased levels after $2 \mathrm{~h}(t=17.3,19.1$ and 29.4 , respectively, p's $<0.05$ ), with increased levels after $6 \mathrm{~h}(t=2.17,0.07$ and 2.09 , respectively, $\mathrm{p}$ 's $<0.05)$, and, between 24 and $48 \mathrm{~h}$, had restored pre-emersion values. Valine, leucine and isoleucine behaved differently, and each had returned to pre-immersion levels after $24 \mathrm{~h}$ and then increased after $48 \mathrm{~h}$ to concentrations significantly higher than their control values $(t=0.76,1.05$ and 0.02 , respectively, p's $<0.05)$.

\section{DISCUSSION}

The haemolymph acidosis and accumulation of metabolic end-products (L-lactate, TA and urate) in groups of Nephrops norvegicus emersed for up to $48 \mathrm{~h}$ are taken to be evidence of impaired gill functioning in the present study. A number of routes of ammonia detoxification are known to occur in decapod crustaceans when body burdens of ammonia are high or ammonia efflux is discontinuous or inhibited. These include the formation of glutamine, glutamic acid, ala- nine or serine, the synthesis of purines and the conversion to urea (Greenaway 1991). In the present study, the presence of serine or the FAAs histidine, aspartic acid and threonine were not found in the haemolymph of $N$. norvegicus, but, after $48 \mathrm{~h}$ of emersion, increased levels of alanine were found. This type of accumulation of alanine was found to be linked with environmental anaerobiosis and activity in the benthic isopod Saduria entomon (Hagerman \& Szaniawska 1990).

The total amino acid value in decapods is known to vary interspecifically and between tissues analysed (Durand et al. 1999, Dooley et al. 2002, Gomez-Jimenez et al. 2004) Control group, pooled haemolymph in the present study had a value of $36.8 \mathrm{mg} \mathrm{l}^{-1}\left(0.44 \mathrm{mmol} \mathrm{l}^{-1}\right)$, a value lower than that found for the portunid crabs Carcinus maenas and Necora puber (Durand et al.1999), but in good accordance with the $36.9 \mathrm{mg} \mathrm{l}^{-1}$ found in another homarid, Homarus gammarus, by Camien et al. (1951 cited in Florkin \& Schoffeniels 1969).

Glycine, alanine and proline were the most abundant FAAs found; their levels were comparable to those found in spiny lobster by Yamanaka \& Shimada (1996). These 3 amino acids are responsible for the rapid, important adjustments necessary for osmoregulation following changes in osmotic stress (Chen \& Chen 2000).

Increased haemolymph L-lactate levels are indicative of energy production under anaerobiosis, and here showed no increase during the first $24 \mathrm{~h}$ of emersion. A transient increase had occurred after $48 \mathrm{~h}$, with levels rising 19-fold (from $0.03 \pm 0.02$ to $0.57 \pm 0.23 \mathrm{mmol} \mathrm{l}^{-1}$ ) indicating that the switch to anaerobic metabolism was possibly delayed whilst some oxygenated water remained in the gill chambers. Between 48 and $72 \mathrm{~h}$ of emersion, haemolymph L-lactate decreased to $0.28 \pm 0.17 \mathrm{mmol} \mathrm{l}^{-1}(\mathrm{p}<0.05)$ and continued this trend to regain pre-emersion levels within $12 \mathrm{~h}$ of being re-immersed. Presumably, these changes when re-immersed are due to the resumption of aerobiosis when ${ }_{L}$-lactate is reoxidised to pyruvate, but the explanation for the decrease during prolonged emersion, which has been repeated in duplicate experiments, requires further study, although it suggests that oxygen became available from some source.

Unlike L-lactate, haemolymph urate levels did not increase significantly during the first $48 \mathrm{~h}$ of emersion, despite showing a trend of increase from 0.04 to $0.11 \mathrm{mmol} \mathrm{l}^{-1}$. During emersion, urate has been found to increase in the haemolymph of other crustaceans 
(Regnault 1992, Durand \& Regnault 1998) and has been shown to modulate $\mathrm{HcyO}_{2}$ affinity (Morris et al. 1985, 1986). The haemolymph urate did show a similar trend to the L-lactate in dropping to control levels between 48 and $72 \mathrm{~h}$ emersion, although this change was not statistically significant. Further study is needed, but, if, as the present findings suggest, Nephrops norvegicus is able to resume a measure of aerobic metabolism under prolonged emersion, any oxygen made available (possibly via an altered $\mathrm{HcyO}_{2}$ affinity) could be utilised to catabolise urate to urea as a detoxification route and would be of considerable survival value to the species.

De novo synthesis of urate using ammonia as the nitrogen source is possible and known to occur in the anomuran land crab Birgus latro (Greenaway \& Morris 1989) and in the gecarcinid land crab Gecarcoidea natalis (Linton \& Greenaway 1997). Linton \& Greenaway (1998) have suggested this may be a general crustacean ability. In the present study, despite its low solubility, haemolymph urate decreased rapidly following re-immersion but it seems unlikely that it was first converted to ammonia, as haemolymph TA levels remained low during the first hour. Moreover, despite a high initial post-re-immersion TA efflux, it took $24 \mathrm{~h}$ to restore control values of haemolymph urate.

Hypoxia-induced haemocyanin synthesis has been found in the homarids Homarus americanus (Senkbeil \& Wriston 1981) and Nephrops norvegicus (Hagerman \& Uglow 1985). Control group haemocyanin levels found in these studies are similar to those given elsewhere for this species (Hagerman \& Uglow 1985, Hagerman \& Baden 1988), but haemocyanin concentration in the present study was found to have a linear, negative relationship with emersion duration (Fig. 1). Despite decreased levels of haemolymph L-lactate and urate occurring between 48 and $72 \mathrm{~h}$ of emersion, haemocyanin showed no evidence of returning to control levels until re-immersion, $2 \mathrm{~h}$ after which normal levels were restored.

Haemolymph TA levels were found to be linearly and positively-related to emersion duration (Fig. 1). Normally, such an increase would allow some compensation for an acidosis but, during emersion, transgill ammonia efflux is reduced and the excretion of $\mathrm{NH}_{4}{ }^{+}$- a possible route for $\mathrm{H}^{+}$removal - would not be effective in compensating for the decrease in haemolymph pH (Danford et al. 2002). The haemolymph did become more acidic directly with emersion duration and, with the emersion-dependent increases in haemolymph ammonia, L-lactate and urate, the findings parallel those for Homarus gammarus (Taylor \& Whiteley 1989), Jasus edwardsii (Morris \& Oliver 1999a,b) and Cancer pagurus (Danford et al. 2002). Taylor \& Wheatly (1981) mention that sustained haemolymph acidosis evokes a compensatory increase in circulating $\mathrm{HCO}_{3}{ }^{-}$. Although $\mathrm{HCO}_{3}{ }^{-}$was not measured in the present study, a linear, negative relationship between $\mathrm{pH}$ and emersion duration occurred with no evidence of compensation with up to $48 \mathrm{~h}$ of emersion. Ridgway et al. (2006) suggest that the simultaneous increase in L-lactate is sufficient itself to overwhelm the protein and bicarbonatecarbonic acid haemolymph buffering capacity; however, in these studies the haemolymph $\mathrm{pH}$ began to increase between 48 and $72 \mathrm{~h}$ emersion and continued after re-immersion. This raises the possibility that Nephrops norvegicus may have the ability to switch to an alternative anaerobic pathway to facilitate some $\mathrm{CO}_{2}$ efflux under humid conditions. In fact, all of the variables measured here had returned to control values between 48 and $72 \mathrm{~h}$ of emersion.

The haemolymph $\mathrm{Ca}^{2+}, \mathrm{K}^{+}$and $\mathrm{Mg}^{+}$concentrations were directly related with emersion duration over the first $48 \mathrm{~h}$. $\mathrm{Ca}^{2+}$ continued to rise during the $72 \mathrm{~h}$ emersion period and decreased rapidly again to control values following re-immersion. This contrasted with $\mathrm{K}^{+}$ and $\mathrm{Mg}^{+}$concentrations which both dropped $(\mathrm{p}>0.05)$ between 48 and $72 \mathrm{~h}$ emersion to control values. Both $\mathrm{Ca}^{2+}$ and $\mathrm{Mg}^{+}$help maintain $\mathrm{HcyO}_{2}$ affinity under hypoxia (Mangum 1983, McMahon 2001) and hypoxia is known to evoke increased circulating $\mathrm{Ca}^{2+}$ in a variety of crustacean species (De Fur et al. 1980, Hagerman \& Uglow 1985, Morris et al. 1985). High circulating $\mathrm{Mg}^{+}$levels are regarded as being negatively related to the general activity levels of crustacean species (Robertson 1949, Florkin 1960, Walters \& Uglow 1981, Frederich et al. 2000), and this may offer a partial explanation for the observed drop in haemolymph $\mathrm{Mg}^{+}$ level and increased whole individual activity found here between 48 and $72 \mathrm{~h}$ emersion.

Haemolymph protein and copper levels showed no significant changes during the present study, indicating maintenance of regulatory activities (Bryan 1968, Devescovi \& Lucu 2003) and an absence of any hypoxia-induced variation (Boone \& Schoffeniels 1979, Senkbeil \& Wriston 1981, Depledge \& Bjerregaard 1989). These results possibly reflect the low metabolic rates induced by the low temperature $\left(5 \pm 1^{\circ} \mathrm{C}\right)$ used for this investigation, which were lower than those used in the studies cited above.

It can be concluded that Nephrops norvegicus under prolonged hypoxia at $5^{\circ} \mathrm{C}$ is able to use a suite of compensatory mechanisms in order to maintain its energy production, which confirms the findings of some previous studies. However, the apparent ability to switch metabolic pathways after $>48 \mathrm{~h}$ emersion, as evidenced by the decrease in haemolmph L-lactate levels and the restoration of levels of physical activity, haemolymph $\mathrm{pH}$ and circulating levels of urate, FAAs, and major ions 
to normal (control) levels, appears not to have been reported before. These patterns of changes differed from that of the haemolymph TA levels, which continued to increase linearly throughout emersion. The lobsters appeared to partially compensate for the post $48 \mathrm{~h}$ emersion increased levels by increasing the production, hence relative proportions, of other less toxic nitrogenous metabolites. This could be a result of the low temperature used (cf. most other published results, e.g. Taylor \& Whiteley 1989, Regnault 1992, Morris \& Oliver 1999a) and the unusually long emersion times (themselves a consequence of the low temperature). The findings have considerable ecological implications for a burrow-dwelling, benthic species which may experience episodic hypoxia events. The commercial implications are also important for a species which currently provides $9 \%$ of the total UK landings and $18 \%$ of their value. Further work on associated aspects of these findings are completed and being prepared for publication.

Acknowledgements. These studies were partially funded by a contract from the Irish Fisheries Board. The authors thank Sutherland Fish and Game, Scotland for supplying the trapcaught specimens. This research was conducted in accordance with institutional, national and international guidelines concerning the use of animals in research.

\section{LITERATURE CITED}

Boone WR, Schoffeniels E (1979) Haemocyanin synthesis during hypo-osmotic stress in the shore crab Carcinus maenas (L). Comp Biochem Physiol 63:207-214

Bridges CR (2001) Modulation of haemocyanin oxygen affinity: properties and physiological implications in a changing world. J Exp Biol 204:1021-1032

Bryan GW (1968) Concentrations of zinc and copper in the tissues of decapod crustaceans. J Mar Biol Assoc UK 48: 303-321

Burnett LE (1992) Integrated function of the respiratory pigment, haemocyanin in crabs. Am Zool 28:125-135

Chen JM, Chen JC (2000) Study on the free amino acid levels in the haemolymph, gill, hepatopancreas and muscle of Penaeus monodon exposed to elevated ambient ammonia. Aquat Toxicol 50:27-37

Claybrook DL (1983) Nitrogen metabolism. In: Mantel LH (ed) The biology of Crustacea: internal anatomy and physiological regulation, Vol 5. Academic Press, New York, p 163-213

Danford AR, Uglow RF, Garland J (2001a) Effect of long haul international transport on lobster haemolymph constituents and nitrogen metabolism. In: Paust BC, Rice AA (eds) Marketing and shipping live aquatic products: Proc 2nd Int Conf Exhib, Nov 1999, Seattle, WA. University of Alaska Sea Grant, Fairbanks, AK, p 9-18

Danford AR, Uglow RF, Rosas C (2001b) Physiological responses of blue crabs (Callinectes sp.) to procedures used in the soft crab fishery in La Laguna de Terminos, Mexico. In: Paust BC, Rice AA (eds) Marketing and shipping live aquatic products: Proc 2nd Int Conf Exhib, Nov 1999, Seattle, WA. University of Alaska Sea Grant, Fairbanks, AK, p 1-8
Danford AR, Hagerman L, Uglow RF (2002) Effects of emersion and elevated haemolymph ammonia on haemocyanin-oxygen affinity of Cancer pagurus (L). Mar Biol 141:1019-1027

DeFur PL (1988) Systemic respiratory adaptations to air exposure in intertidal decapod crustaceans. Am Zool 28: $115-124$

DeFur PL, Wilkes PRH, McMahon BR (1980) Non-equilibrium acid-base status in Cancer productus: role of exoskeletal carbonate buffers. Respir Physiol 42:247-261

> Depledge MH, Bjerregaard P (1989) Haemolymph protein composition and copper levels in decapod crustaceans. Mar Environ Res 27:115-126

> Devescovi M, Lucu C (2003) Growth of tissues related to haemolymph copper throughout the moult cycle of the lobster Homarus gammarus. Mar Ecol Prog Ser 247: 165-172

Dooley PC, Crouch PJ, West JM (2002) Free amino acids in claw muscle and haemolymph from Australian freshwater crayfish at different stages of the moult cycle. Comp Biochem Physiol 131:625-637

> Durand F, Regnault M (1998) Nitrogen metabolism of two portunid crabs, Carcinus maenas and Necora puber, during prolonged air exposure and subsequent recovery: a comparative study. J Exp Biol 201:2515-2528

$>$ Durand F, Chausson F, Regnault M (1999) Increases in tissue free amino acid levels in response to prolonged emersion in marine crabs: an ammonia-detoxifying process efficient in the intertidal Carcinus maenas but not in the subtidal Necora puber. J Exp Biol 202:2191-2202

Florkin M (1960). Blood chemistry. In: Waterman T (ed) The physiology of Crustacea. Academic Press, New York, p 141-171

Florkin M, Schoffeniels E (1969) Molecular approaches to ecology. Academic Press, New York

Frederich M, DeWachter B, Sartoris FJ, Pörtner HO (2000) Cold tolerance and the regulation of cardiac performance and haemolymph distribution in Maja squinado (Crustacea: Decapoda). Physiol Biochem Zool 73:406-415

Gilles R (1979). Intracellular organic osmotic effectors. In: Gilles (ed) Mechanisms of osmoregulation in animals: maintenance of cell volume. Wiley, New York p 111-154

Gomez-Jimenez S, Urias-Reyes AA, Vazquez-Ortiz F, Hernandez-Watanabe G (2004) Ammonia efflux rates and free amino acid levels in Litopenaeus vannamei postlarvae during sudden salinity changes. Aquaculture 233:573-581

Greenaway P (1991) Nitrogenous excretion in aquatic and terrestrial crustaceans. Mem Qld Mus 31:215-227

Greenaway P, Morris S (1989) Adaptations to a terrestrial existence by the robber crab, Birgus latro L. III. Nitrogenous excretion. J Exp Biol 143:333-346

Hagerman LT, Baden SP (1988) Nephrops norvegicus: field study of effects of oxygen deficiency on haemocyanin. J Exp Mar Biol Ecol 116:135-142

> Hagerman LT, Szaniawska A (1990) Anaerobic metabolic strategy of the glacial relict isopod Saduria (Mesidotea) entomon. Mar Ecol Prog Ser 59:91-96

- Hagerman LT, Uglow RF (1985) Effects of hypoxia on the respiratory and circulatory regulation of Nephrops norvegicus. Mar Biol 87:273-278

Hunter DA, Uglow RF (1993) Moult stage-dependent variability of haemolymph ammonia and total protein levels in Crangon crangon (L.) (Crustacea, Decapoda). Ophelia 37:41-50

- Linton SM, Greenaway P (1997) Urate deposits in the gecarcinid land crab Gecarcoidea natalis are synthesised de novo from excess dietary nitrogen. J Exp Biol 200: 2347-2354 
Linton SM, Greenaway P (1998) Enzymes of urate synthesis and catabolism in the Gecarcinid land crab Gecarcoidea natalis. Exp Biol Online 3:5

Mangum CP (1983) Oxygen transport in the blood. In: Mantel LH (ed) The biology of Crustacea, Vol 5: Internal anatomy and physiological regulation. Academic Press, New York, p 373-429

McMahon BR (2001) Growth of tissues related to haemolymph copper throughout the moult cycle of the lobster Homarus gammarus. Mar Ecol Prog Ser 247:165-172

Morris S (1990) Organic ions as modulators of respiratory pigment function during stress. Physiol Zool 63:253-287

Morris S (1991) Respiratory gas exchange and transport in crustaceans: ecological determinants. Mem Qld Mus 31: 241-261

Morris S, Bridges CR (1985) An investigation of haemocyanin oxygen affinity in the semi-terrestrial crab Ocypode saratan Forsk. J Exp Biol 117:119-132

Morris S, Oliver S (1999a) Circulatory, respiratory and metabolic response to emersion and low temperature of Jasus edwardsii: simulation studies of commercial shipping methods. Comp Biochem Physiol 122:299-308

Morris S, Oliver S (1999b) Respiratory gas transport, haemocyanin function and acid-base balance in Jasus edwardsii during emersion and chilling: simulation studies of commercial shipping methods. Comp Biochem Physiol 122: 309-321

Morris S, Bridges CR, Grieshaber MK (1985) A new role for uric acid: modulator of haemocyanin oxygen affinity in crustaceans. J Exp Zool 235:135-139

Morris S, Tyler-Jones R, Taylor EW (1986) The regulation of haemocyanin oxygen affinity during emersion of the crayfish Austropotamobius pallipes: I. An in vitro investigation of the interactive affects of calcium and L-lactate on oxygen affinity. J Exp Biol 121:302-314

Rebelo MF, Santos EA, Monserrat JM (1999) Ammonia exposure of Chasmagnathus granulate (Crustacea, Decapoda) Dana, 1851: accumulation in haemolymph and effects on osmoregulation. Comp Biochem Physiol 122:429-435

Regnault M (1992) Effect of aerial exposure on nitrogen metabolism in the crab Cancer pagurus. J Exp Zool 264: $372-380$

Initial editorial responsibility: Anne Berit Skiftesvik, Storebø, Norway; final editorial responsibility: John Austin,

Oldendorf/Luhe, Germany
Ridgway ID, Taylor AC, Atkinson RJA, Stentiford GD, Chang ES, Chang SA, Neil DM (2006) Morbidity and mortality in Norway lobsters, Nephrops norvegicus: physiological, immunological and pathological effects of aerial exposure. J Exp Biol Ecol 328:251-264

Robertson JD (1949) Ionic regulation in some marine invertebrates. J Exp Biol 26:182-206

Schmitt ASC, Uglow RF (1997) Physiological requirements and techniques for the storage of Nephrops norvegicus (L.) during live marketing: a review. In: Paust BC, Rice AA (eds) Marketing and shipping live aquatic products: Proc 2nd Int Conf Exhib, Nov 1999, Seattle, WA. University of Alaska Sea Grant, Fairbanks, AK, p 172-178

Senkbeil EG, Wriston JC (1981) Hemocyanin synthesis in the American lobster Homarus americanus. Comp Biochem Physiol 68:163-171

Taylor EW, Wheatly MG (1981) The effect of long-term aerial exposure on heart rate, ventilation, respiratory gas exchange and acid-base status in the crayfish Austropotamobius pallipes. J Exp Biol 92:109-124

Taylor EW, Whiteley NM (1989) Oxygen transport and acidbase balance in the haemolymph of the lobster, Homarus gammarus, during aerial exposure and re-submersion. J Exp Biol 144:417-436

Terwilliger NB (1998) Functional adaptations of oxygentransport proteins. J Exp Biol 201:1085-1098

Truchot JP (1983). Regulation of acid-base balance. In: Mantel LH (ed) The biology of Crustacea, Vol 5: Internal anatomy and physiological regulation. Academic Press, New York, p 431-457

Truchot JP (1992) Respiratory function of arthropod hemocyanins. Adv Comp Environ Physiol 13:377-410

> Uglow RF (1969) Haemolymph protein concentrations in portunid crabs. I. Studies on adult Carcinus maenas. Comp Biochem Physiol 30:1083-1090

Walters NJ, Uglow RF (1981) Haemolymph magnesium and relative heart activity of some species of marine decapod crustaceans. J Exp Mar Biol Ecol 55:255-265

Yamanaka H, Shimada R (1996) Post-mortem biochemical changes in the muscle of Japanese spiny lobster during storage. Fish Sci 62:821-824

Submitted: October 6, 2006; Accepted: August 13, 2008 Proofs received from author(s): November 11, 2008 